\title{
Corrigendum: In Vivo Pooled Screening: A Scalable Tool to Study the Complexity of Aging and Age-Related Disease
}

\author{
Martin Borch Jensen ${ }^{1 *}$ and Adam Marblestone ${ }^{2,3 *}$ \\ ${ }^{1}$ Gordian Biotechnology, San Francisco, CA, United States, ${ }^{2}$ Astera Institute, San Francisco, CA, United States, ${ }^{3}$ Federation of \\ American Scientists, Washington D.C., CA, United States
}

Keywords: in vivo, pooled screening, direct in vivo screening, aging models, animal models, gene therapy, single cell sequencing, barcoding

\section{A corrigendum on}

In Vivo Pooled Screening: A Scalable Tool to Study the Complexity of Aging and Age-Related Disease

by Borch Jensen, M., and Marblestone, A. (2021). Front. Aging 2:714926. doi:10.3389/fragi.2021.714926

In the original article, there was a mistake in Table $\mathbf{1}$ as published. A typo caused the entry for "Optimal payload size" for AAV to be listed as $3-4.5 \mathrm{~kb}$, rather than the intended $4-4.5 \mathrm{~kb}$. The corrected Table 1 appears below.

The authors apologize for this error and state that this does not change the scientific conclusions of the article in any way. The original article has been updated.

Edited and reviewed by: Christian G. Riedel, Karolinska Institutet (KI), Sweden

*Correspondence: Martin Borch Jensen martin@gordian.bio Adam Marblestone adam@astera.org

Specialty section:

This article was submitted to Interventions in Aging, a section of the journal Frontiers in Aging

Received: 29 October 2021 Accepted: 17 November 2021 Published: 03 December 2021

Citation: Borch Jensen $M$ and Marblestone $A$ (2021) Corrigendum: In Vivo Pooled Screening: A Scalable Tool to Study the Complexity of Aging and Age-

Related Disease.

Front. Aging 2:804856.

doi: 10.3389/fragi.2021.804856
TABLE 1 | Delivery modalities for in vivo pooled screening

\begin{tabular}{|c|c|c|c|c|c|}
\hline & AAV & Lentivirus & Adenovirus & $\begin{array}{l}\text { Lipid nanoparticle } \\
\text { (with mRNA/siRNA) }\end{array}$ & $\begin{array}{l}\text { siRNA/antisense } \\
\text { oligos }\end{array}$ \\
\hline $\begin{array}{l}\text { Targetable tissues } \\
\text { and cell types }\end{array}$ & $\begin{array}{l}\text { Many (liver, muscle, } \\
\text { brain, eye, lung, heart, } \\
\text { and more) }\end{array}$ & Many & Many & $\begin{array}{l}\text { Mainly hepatocytes, } \\
\text { vasculature reported }\end{array}$ & $\begin{array}{l}\text { Mainly liver and } \\
\text { kidney, neurons with } \\
\text { direct injection }\end{array}$ \\
\hline $\begin{array}{l}\text { Inter- and intra- } \\
\text { tissue spread }\end{array}$ & Medium-high & Low & Low & Medium & High \\
\hline $\begin{array}{l}\text { Duration of } \\
\text { treatment possible }\end{array}$ & $\begin{array}{l}\text { Stable episomal } \\
\text { expression in non- } \\
\text { dividing cells for } \\
\text { months+ }\end{array}$ & $\begin{array}{l}\text { Stable integration } \\
\text { in dividing and non- } \\
\text { dividing }\end{array}$ & $\begin{array}{l}\text { Stable episomal } \\
\text { expression in non- } \\
\text { dividing cells for } \\
\text { months+ }\end{array}$ & $\begin{array}{l}\text { Days to weeks, unless } \\
\text { gene editing modalities } \\
\text { delivered }\end{array}$ & Days to weeks \\
\hline $\begin{array}{l}\text { Optimal payload } \\
\text { size }\end{array}$ & $4-4.5 \mathrm{~kb}$ & $7-8 \mathrm{~kb}$ & $8-30 \mathrm{~kb}$ & Any & $<100 \mathrm{bp}$ \\
\hline $\begin{array}{l}\text { Payload vector } \\
\text { construction }\end{array}$ & Moderate & Moderate & Hard & Easy & Easy but expensive \\
\hline Immunogenicity & Low & Medium & High & Low & Low-High \\
\hline
\end{tabular}

Publisher's Note: All claims expressed in this article are solely those of the authors and do not necessarily represent those of their affiliated organizations, or those of the publisher, the editors and the reviewers. Any product that may be evaluated in this article, or claim that may be made by its manufacturer, is not guaranteed or endorsed by the publisher.

Copyright (C) 2021 Borch Jensen and Marblestone. This is an open-access article distributed under the terms of the Creative Commons Attribution License (CC BY). The use, distribution or reproduction in other forums is permitted, provided the original author(s) and the copyright owner(s) are credited and that the original publication in this journal is cited, in accordance with accepted academic practice. No use, distribution or reproduction is permitted which does not comply with these terms. 